\title{
lodine adequacy in reproductive age and pregnant women living in the Western region of Saudi Arabia
}

\author{
Firas Azzeh ${ }^{1+}$ and Bassem Refaat ${ }^{2^{*}}$ (D)
}

\begin{abstract}
Background: Despite the serious maternal and foetal complications associated with iodine deficiency during pregnancy, surveys related to pregnant women in the Kingdom of Saudi Arabia (KSA) are lacking. This study, therefore, measured urine iodine concentrations (UIC) alongside the potential socioeconomic factors contributing towards iodine inadequacy in reproductive age and pregnant Saudi women from the Western province of KSA.

Methods: Spot urine samples were collected from 1222 pregnant and 400 age-matched non-pregnant/nonlactating reproductive age women. The socioeconomic characteristics were obtained through a structured questionnaire. The WHO criteria for iodine sufficiency in non-pregnant (100-199 $\mu \mathrm{g} / \mathrm{L})$ and pregnant $(150-249 \mu \mathrm{g} / \mathrm{L})$ women were applied.

Results: The median UIC in the non-pregnant women (101.64 $\mu \mathrm{g} / \mathrm{L} ;$ IQR: 69.83-143.55) was at the lowermost WHO recommended cut-off, whereas the pregnant group was iodine deficient (112.99 $\mu \mathrm{g} / \mathrm{L} ;$ IQR: 81.01-185.57). Moreover, the median UIC was below adequacy across the different trimesters. The use of non-iodised salt significantly increased the risk of iodine deficiency in the non-pregnant $(\mathrm{OR}=2.052 ; 95 \% \mathrm{Cl}$ : 1.118-3.766) and pregnant women $(\mathrm{OR}=3.813$; $95 \% \mathrm{Cl}: 1.992-7.297)$, whereas taking iodine supplements significantly lowered the risk in both groups $(\mathrm{OR}=0.364 ; 95 \% \mathrm{Cl}: 0.172-0.771$ and $\mathrm{OR}=0.002 ; 95 \% \mathrm{Cl}$ : 0.001-0.005, respectively). Passive smoking was also an independent risk factor for iodine deficiency in the non-pregnant $(\mathrm{OR}=1.818 ; 95 \% \mathrm{Cl}$ : 1.097-3.014) and pregnant $(\mathrm{OR}=1.653 ; 95 \% \mathrm{Cl}: 1.043-2.618)$ groups. Additionally, BMI correlated independently and significantly with median $\mathrm{UIC}$ in the non-pregnant and pregnant populations. However, multiparity $(\mathrm{OR}=3.091 ; 95 \% \mathrm{Cl}: 1.707-5.598)$ and earning below the minimum wage $(2.520 ; 95 \% \mathrm{Cl}$ : $1.038-6.119)$ significantly increased the risk of iodine deficiency only in the non-pregnant women.
\end{abstract}

Conclusions: This study is the first to show borderline iodine sufficiency in reproductive age Saudi women from the Western province, whereas mild iodine deficiency was observed in the pregnant population and could represent a serious public health problem. This study also advocates the necessity to establish routine iodine dietary advice services by the health authorities to foster adequate iodine intake in pregnant women to avoid the perilous consequences of iodine deficiency on maternal-foetal health.

Keywords: lodine supplement, lodine-measurement, Pregnancy and nutrition

\footnotetext{
* Correspondence: barefaat@uqu.edu.sa; bassem.refaat@yahoo.co.uk

${ }^{\dagger}$ Firas Azzeh and Bassem Refaat contributed equally to this work.

${ }^{2}$ Laboratory Medicine Department, Faculty of Applied Medical Sciences,

Umm Al-Qura University, Al Abdeyah, Holy Makkah, PO Box 7607, Makkah,

Saudi Arabia

Full list of author information is available at the end of the article
}

(C) The Author(s). 2020 Open Access This article is licensed under a Creative Commons Attribution 4.0 International License, which permits use, sharing, adaptation, distribution and reproduction in any medium or format, as long as you give appropriate credit to the original author(s) and the source, provide a link to the Creative Commons licence, and indicate if changes were made. The images or other third party material in this article are included in the article's Creative Commons licence, unless indicated otherwise in a credit line to the material. If material is not included in the article's Creative Commons licence and your intended use is not permitted by statutory regulation or exceeds the permitted use, you will need to obtain permission directly from the copyright holder. To view a copy of this licence, visit http://creativecommons.org/licenses/by/4.0/ The Creative Commons Public Domain Dedication waiver (http://creativecommons.org/publicdomain/zero/1.0/) applies to the data made available in this article, unless otherwise stated in a credit line to the data. 


\section{Background}

Iodine is essential for the synthesis of thyroid hormones, and suboptimal intake of this nutrient at the periconceptual and/or during pregnancy has been linked with maternal goitre and hypothyroidism [1, 2]. Iodine deficiency during pregnancy also significantly increases the risk of delayed neurodevelopment and poor cognitive functions of the offspring $[3,4]$. Although many countries have implemented the universal salt iodisation (USI) policy to ensure adequate access to iodine by the general public $[5,6]$, numerous reports from developed and developing countries have demonstrated high rates of iodine insufficiency among pregnant women [7-11]. Accordingly, many researchers have emphasised the need for alternative means (e.g. iodine supplements) to ensure adequate iodine intake during pregnancy [7-11], and the World Health Organisation (WHO) has recommended that the urine iodine concentrations (UIC) should range between 150 to $250 \mu \mathrm{g} / \mathrm{L}$ to assure adequacy during pregnancy [12].

About $90 \%$ of ingested iodine from diet and/or supplement is excreted by the kidney and, measuring UIC in spot samples and estimating 24-h urine iodine excretion (24-h UIE) are reliable approaches for assessing iodine status [13-15]. Surveying school-age children (SAC) is also the currently accepted method for evaluating iodine intake within a population since they are easy to access and are believed to reflect the nutritional status of their families [16]. However, the most recent report by the Iodine Global Network (IGN) in 2019 has revealed that 29 countries reported iodine deficiency in pregnant women albeit that their SAC populations were sufficient [5]. Hence, it has been proposed that pregnant women should be surveyed independently from SAC to precisely measure their iodine status [7-11]. Additionally, the updated guidelines by the United Nations International Children's Emergency Fund (UNICEF) has also recommended that iodine should be assessed in different subsets of a population, especially those who are vulnerable for deficiency [17].

In the Kingdom of Saudi Arabia (KSA), thyroid disorders are common among the general population at the different ages [18-21] and goitre was frequently reported in Saudi children, particularly among those who were living in high altitude areas of the kingdom [22, 23]. Alissa et al. (2009) followed the WHO recommended median UIC cut-off values for iodine adequacy, and their results revealed severe deficiency in their enrolled hypothyroid patients as well as healthy participants from the Western region of KSA [24]. Although KSA is currently classified by the IGN (2019) as iodine sufficient based on a national survey of SAC in 2012 [5], more recent national studies have revealed marked iodine deficiency and high prevalence of goitre in their SAC populations $[25,26]$. According to another recent national survey, KSA has also adopted the USI policies since 1995 and most of the locally available salt is adequately iodised (15-40 ppm) [27]. However, salt iodisation is not obligatory in the kingdom, only $70 \%$ of the Saudi households were found to consume iodised salt, and the numbers are below the WHO references [27]. Concomitantly, we have previously shown that 26.8 and $4.8 \%$ of pregnant Saudi women from the Western region had hypothyroidism and isolated hypothyroxinaemia, respectively [28]. However, currently there is no report on iodine status among reproductive age and pregnant Saudi women.

Hence, this study measured iodine adequacy in nonpregnant, non-lactating reproductive age Saudi women as well as in pregnant Saudi women at the different trimesters. Additionally, the socio-economic characteristics were collected to identify the factors that could contribute to iodine deficiency. A better understanding about iodine status in the targeted populations could enlighten the health authorities and policymakers regarding the magnitude of iodine deficiency and may possibly support the development of appropriate policies regarding the screening and prevention of iodine inadequacy during pregnancy.

\section{Methods \\ Study design}

This non-randomised, cross-sectional study was conducted from March 2017 to May 2019, and ethical approval (AMSEC 21-16-02-2017) was obtained from the Faculty of Applied Medical Sciences Ethics Committee in Umm Al-Qura University. The study populations included 1222 apparently healthy pregnant Saudi women (18-44 years) at the different trimesters and who were recruited from the antenatal care unit in the Medical Centre of Umm Al-Qura University in Makkah City. Another 400 primi- or multiparous non-pregnant, non-lactating, reproductive age Saudi women, and who had no relevant bad obstetrics history were also recruited from the same centre during the routine vaccination of their children. All the pregnant and non-pregnant participants had no current symptoms/signs or history of thyroid disorders, chronic diseases (e.g. hypertension, diabetes mellitus, etc.), gestational related medical disorders (e.g. pre-eclampsia, gestational diabetes, anaemia, etc.) or autoimmune diseases. According to the 2017 reports issued by the Saudi General Authority for Statistics and Ministry of Health, the total numbers of reproductive age and pregnant Saudi women in the Western region of KSA were 1,140,185 and 29,701 , respectively $[29,30]$. The Epi Info ${ }^{\text {tw }}$ software was used (https://www.cdc.gov/epiinfo/index.html), and the minimal required sample sizes were 384 non-pregnant and 379 pregnant women to achieve a study power of $95 \%$. 
A fresh spot urine sample $(5 \mathrm{ml})$ was collected from each woman in a sterile urine container between 9:00 am and 1:00 pm and the samples were stored at $-70{ }^{\circ} \mathrm{C}$ till transported to the Research Laboratories of the Faculty of Applied Medical Sciences in Umm Al-Qura University for processing. Additionally, the socioeconomic characteristics were obtained through a structured questionnaire that included information related to age (years), pre-pregnancy and/or current weight $(\mathrm{Kg})$ and height $(\mathrm{cm})$ to calculate the body mass index (BMI), parity, type of salt intake, the use of daily iodine-containing supplements, family size, education level, employment status, total monthly income, smoking, residency and gestational age at the time of sample collection from the pregnant population. The question related to the use of iodised salt was categorised as previously reported into non-iodised, iodised and I don't know [31].

\section{Urine Creatinine concentrations}

Urine creatinine concentrations were measured on Cobas e411 (Roche Diagnostics International Ltd.; Risch-Rotkreuz, Switzerland) according to the manufacturer's protocol. The predicted 24-h urine creatinine excretion (24-h Cr; g/day) was calculated by the previously published equation as follow [32]:

Predicted 24-h Cr for females $=(0.00163 \times[140$ - age (years) $] \times\left[\right.$ weight $(\mathrm{kg})^{1.5} \times$ height $\left.(\mathrm{cm})^{0.5}\right] \times[1+0.18 \times($ black $=$ 1 , nonblack $=0)] \times\left[1.429-0.0198 \times\right.$ BMI $\left.\left.\left(\mathrm{kg} / \mathrm{m}^{2}\right)\right] / 1000\right)$.

\section{Urine iodine concentrations}

All the chemicals were analytical grade from SigmaAldrich Co. (MO, USA) and the required working solutions for measuring urine iodine were prepared as previously described [15]. The spot urine samples were processed in 96-well clear polystyrene flat-bottomed microplates (Thermo Fisher Scientific, CA, USA) and on a fully automated ELISA machine (Human Diagnostics, Wiesbaden, Germany) to measure the UIC according to the principles of the Sandell-Kolthoff method [15]. Low $(13 \mu \mathrm{g} / \mathrm{l})$, intermediate $(102 \mu \mathrm{g} / \mathrm{l})$ and high $(203 \mu \mathrm{g} / \mathrm{l})$ iodine calibrators were also processed five times to measure the assay performances. The intra-assay coefficient of variation was $5.7,4.3$ and $4.1 \%$ for the low, intermediate and high calibrators, respectively. Additionally, the interassay precision was $10 \%$ for the low, $7 \%$ for the intermediate and $4.5 \%$ for the high calibrators.

The 24-h UIE was calculated according to the previously published equation as follow [14]: Spot urine [Iodine/Creatinine $(\mu \mathrm{g} / \mathrm{g})] \times$ predicted $24-\mathrm{h} \mathrm{Cr}(\mathrm{g} /$ day $)$. The amount of 24-h UIE were classified according to the WHO reference values for iodine adequacy as follow: deficiency $(<100$ and $<150 \mu \mathrm{g} /$ day $)$, sufficiency (100-199 and $150-249 \mu \mathrm{g} /$ day $)$ and excess $(\geq 200$ and $\geq 250 \mu \mathrm{g} /$ day) for non-pregnant and pregnant women, respectively [13].

\section{Statistical analysis}

Statistical analysis was done with SPSS software version 25 (New York, USA), and $P<0.05$ was considered statistically significant. The Kolmogorov-Smirnov test for normality and Levene test for homogeneity were performed for continuous data that were expressed either as mean \pm standard deviation (SD) or median with the interquartile range (IQR) depending on data normality. Ordinal and discontinuous data were shown as numbers and percentages, and cross-tabulation followed by Chi square $\left(x^{2}\right)$ test were applied for frequency analysis. Based on data normality, one-way ANOVA or KruskalWallis were used to compare between more than two groups followed by either Tukey's HSD or GamesHowell post-hoc tests according to variance equality. Multinomial regression analysis was also performed to identify the socioeconomic predictors of iodine status in each of the study populations.

\section{Results}

The socioeconomic characteristics of the study groups

The study raw data are available as Supplementary File 1. The mean \pm SD of age and BMI in the non-pregnant population were $29.1 \pm 7.3$ years and $24.03 \pm 5.4 \mathrm{~kg} / \mathrm{m}^{2}$, respectively. The majority of participants were primiparous $(n=228 ; 57 \%)$ and their families comprised $\leq$ four members $(n=236 ; 59 \%)$. Nineteen $(4.7 \%)$ women were illiterate, whereas 34 (8.5\%) had primary education, 125 (31.2\%) had secondary education, and the remaining 222 subjects $(55.5 \%)$ had a university degree. However, unemployment was predominant $(n=311 ; 77.8 \%)$. While $14 \%(n=56)$ reported that their monthly income was below the Saudi national minimum wage (3000 SAR), $37.3 \%(n=159)$ were receiving between 3001 and 5000 SAR, 33.5\% $(n=134)$ were gaining between 5001 and below 10,000 SAR and 15.3\% $(n=61)$ were earning $\geq 10$, 000 SAR. Active and passive smoking were also reported by $5.8 \%(n=23)$ and $34.2 \%(n=137)$, respectively. Moreover, 292 women (73\%) were using iodised salt and the remainders either were using non-iodised salt $(n=84 ; 21 \%)$ or chose 'I don't know' $(n=24 ; 6 \%)$. Finally, 46 women (11.5\%) were using daily iodine supplements $(150 \mu \mathrm{g} /$ day $)$. The socio-economic characteristics of the non-pregnant population are detailed in Supplementary File 2.

On the other hand, the mean of age was $28.7 \pm 5.7$ years and the mean of pre-conceptional BMI was $25.7 \pm$ $4.7 \mathrm{~kg} / \mathrm{m}^{2}$ in the pregnant group $(n=1222)$. Multigravidity $(n=956 ; 78.2 \%)$, having more than four family members $(n=786 ; 64.3 \%)$, being a university graduate $(n=$ $694 ; 56.8 \%)$, unemployment $(\mathrm{n}=956 ; 78.2 \%)$ and earning a monthly income between 3001 and 5000 SAR $(n=642$; 
$52.5 \%)$ were common among the pregnant population. Furthermore, the majority was neither active $(n=1158$; $94.8 \%)$ nor passive $(n=792 ; 64.8 \%)$ smokers. Meanwhile, $71.5 \%(n=874)$ were using iodised salt, $21.8 \%(n=266)$ were utilising non-iodised salt and 6.7\% $(n=82)$ answered by 'I don't know'. Additionally, only 338 (27.7\%) pregnant women reported using iodine supplements $(220 \mu \mathrm{g} /$ day $)$. The sub-analysis also showed that 364 (29.8\%), $352(28.8 \%)$ and $506(41.4 \%)$ women were in the first, second and third trimesters, respectively. Furthermore, the distribution of age, BMI, family size, educational levels, monthly income, active smoking, the use of iodised salt and consumption of iodine supplements were significantly different between the three trimesters (Table 1).

\section{Urine iodine concentrations and associated factors with iodine inadequacy}

\section{A. Non-pregnant population}

The median spot urine iodine and creatinine concentrations together with the $\mathrm{I} / \mathrm{Cr}$ ratio in the entire nonpregnant population were $75.3 \mu \mathrm{g} / \mathrm{L}$ (IQR: 51.6-106.2), $0.73 \mathrm{~g} / \mathrm{L}$ (IQR: 0.62-0.85) and $102.86 \mu \mathrm{g} / \mathrm{g}$ (IQR: 67.6153.2), respectively. Additionally, the estimated 24-h urine $\mathrm{Cr}$ excretion in the non-pregnant women was 1.1 g/L (IQR: 0.97-1.32), whereas the 24-h UIE $(101.64 \mu \mathrm{g} /$ L; IQR: 69.83-143.55) was at the lowest WHO recommended limit for adequate iodine intake for reproductive age women $(100-199 \mu \mathrm{g} / \mathrm{L})$.

The sub-analysis showed that the group of nonpregnant women not using iodine supplements $(n=354$; $88.5 \%)$ had significantly lower spot median UIC (70.5 $\mu \mathrm{g} / \mathrm{L} ;$ IQR: $49.1-96.1$ vs. $120.3 \mu \mathrm{g} / \mathrm{L}$; IQR: $70.4-$ $134.4)$ and $\mathrm{I} / \mathrm{Cr}$ ratio $(98.6 \mu \mathrm{g} / \mathrm{g}$; IQR: $65.8-144.1$ vs. 170.2 $\mu \mathrm{g} / \mathrm{g}$; IQR: 116.4-226.6) compared with those who were taking supplements rich in iodine $(n=46 ; 11.5 \%)$. Furthermore, the 24-h UIE in the non-pregnant individuals not using iodine supplements $(95.2 \mu \mathrm{g} / \mathrm{L}$; IQR: 66.1-131.4) was also significantly lower than the subgroup using supplements $(165.6 \mu \mathrm{g} / \mathrm{L}$; IQR: 95.1-182.4), and the levels were below the WHO recommended levels. However, the median of spot $\mathrm{Cr}$ and estimated 24-h urine $\mathrm{Cr}$ excretion were comparable between both groups.

The regression analysis showed that having $>4$ family members (2.4-fold), earning below the national minimal wage (2.5-fold), passive smoking (1.8-fold) and using non-iodised salt (2-fold) significantly increased the risk of iodine deficiency in the non-pregnant population (Table 2). Contrariwise, primiparity (3-fold) and the consumption of iodine supplements (2.7-fold) significantly decreased the risk of iodine deficiency. Furthermore, low educational level (illiterate; 10-fold and primary education; 4-fold) was the only independent factor that increased the risk of iodine intake above requirements (Table 2), whereas BMI was independently and significantly associated with median UIC in the non-pregnant women (1.084; 95\%CI: 1.010-1.163).

\section{B. Pregnant population}

The spot urine concentrations in the overall pregnant population were $83.69 \mu \mathrm{g} / \mathrm{L}$ (IQR: 60-137.46) for UIC, $0.83 \mathrm{~g} / \mathrm{L}$ (IQR: 0.71-0.97) for creatinine and $102.47 \mu \mathrm{g} / \mathrm{g}$ (IQR: 74.88-151.09) for $\mathrm{I} / \mathrm{Cr}$ ratio. The estimated 24-h urine $\mathrm{Cr}$ median was $1.12 \mathrm{~g} / \mathrm{L}$ (IQR: 0.97-1.32), whereas the 24-h UIE median $(112.99 \mu \mathrm{g} / \mathrm{L}$; QR: 81.01-185.57) was less than the WHO recommended minimal limit for adequate iodine intake during pregnancy $(150-249 \mu \mathrm{g} / \mathrm{L})$.

While the first trimester median spot UIC was significantly lower than the third trimester $(P=0.02)$, the concentrations of both groups were comparable to the second trimester (Fig. 1a). Furthermore, the spot urine creatinine concentrations were similar in the first and second trimesters, and both groups were significantly lower than the third trimester levels (Fig. 1b). However, no significant difference was detected in the $\mathrm{I} / \mathrm{Cr}$ ratio between the three trimesters (Fig. 1c). Although the estimated 24-h urine creatinine was also significantly lower in the first and second trimesters compared with the third trimester (Fig. 1d), the 24-h UIE was only significantly different between the first and third trimesters (Fig. 1e; $P=0.004$ ). Nevertheless, the 24-h UIE levels in each of the three trimesters were below the WHO advocated minimum for adequate iodine during pregnancy (Fig. 1e).

By comparing between the pregnant women with ( $n=$ $338 ; 27.7 \%)$ and without $(n=884 ; 72.3 \%)$ iodine supplements, the median of spot UIC $(70.1 \mu \mathrm{g} / \mathrm{L}$; IQR: $53.1-$ 90.3 vs. $152.3 \mu \mathrm{g} / \mathrm{L}$; IQR: $138.1-166.9)$, Cr $(0.79 \mathrm{~g} / \mathrm{L}$; IQR: $0.7-0.92$ vs. $0.94 \mathrm{~g} / \mathrm{L}$; IQR: $0.81-1.1)$ and $\mathrm{I} / \mathrm{Cr}$ (159.9 $\mu \mathrm{g} / \mathrm{g}$; IQR: $139.2-189.7$ vs. $84.6 \mu \mathrm{g} / \mathrm{g}$; IQR: $65.3-$ 116.6) were significantly higher in the supplement group. Similarly, the median of estimated $24-\mathrm{h}$ Cr $(1.3 \mathrm{~g} / \mathrm{L}$; IQR: 1.1-1.4 vs. $1.1 \mathrm{~g} / \mathrm{L} ; \quad$ IQR: $0.94-1.2)$ and $24-\mathrm{h}$ UIE (205.6 $\mu \mathrm{g} / \mathrm{L}$; IQR: $186.4-225.3$ vs. $94.6 \mu \mathrm{g} / \mathrm{L}$; IQR: $71.4-$ 121.9) were markedly elevated with the use compared with not taking iodine supplements during pregnancy. Moreover, the subgroup utilising iodine supplement had sufficient iodine intake, whereas the women not taking iodine supplements were iodine deficient, as per the WHO cut-off values during pregnancy.

While the use of non-iodised salt (> 3.5-fold) and passive smoking (1.6-fold) were independent factors associated with increased risk of iodine insufficiency during pregnancy, taking iodine supplements was strongly and significantly associated with reduced odds (500-fold) of iodine inadequacy (Table 3). Alternatively, none of the socioeconomic factors increased the risk of iodine intake 
Table 1 The socioeconomic characteristics of the pregnant participants ( $n=1222$ )

\begin{tabular}{|c|c|c|c|c|}
\hline \multirow[t]{2}{*}{ Parameter } & \multicolumn{3}{|l|}{$\begin{array}{l}\text { Pregnant group } \\
(n=1222)\end{array}$} & \multirow[b]{2}{*}{$P$-value } \\
\hline & $\begin{array}{l}\text { First trimester } \\
(n=364 ; 29.8 \%)\end{array}$ & $\begin{array}{l}\text { Second trimester } \\
(n=352 ; 28.8 \%)\end{array}$ & $\begin{array}{l}\text { Third trimester } \\
(n=506 ; 41.4 \%)\end{array}$ & \\
\hline Mean $\pm S D$ of Age (year) & $28.6 \pm 6.2$ & $27.9 \pm 5.5$ & $29.2 \pm 5.4$ & 0.003 \\
\hline Age groups & & & & $<0.001$ \\
\hline $18-<25$ & $132(10.8 \%)$ & $134(10.9 \%)$ & $118(9.7 \%)$ & \\
\hline $25-<35$ & $160(13.1 \%)$ & $172(14.1 \%)$ & $296(24.2 \%)$ & \\
\hline$\geq 35$ & $72(5.9 \%)$ & $46(3.8 \%)$ & $92(7.5 \%)$ & \\
\hline Mean $\pm S D$ of Weight $(\mathrm{kg})$ & $66.4 \pm 13.6$ & $65.9 \pm 13.5$ & $69.1 \pm 13.4$ & 0.001 \\
\hline Mean $\pm S D$ of Height $(\mathrm{cm})$ & $160.8 \pm 7.9$ & $160.9 \pm 7.03$ & $163.3 \pm 8.4$ & $<0.001$ \\
\hline Mean $\pm S D$ of $B M I\left(\mathrm{~kg} / \mathrm{m}^{2}\right)$ & $25.8 \pm 5.5$ & $25.4 \pm 4.6$ & $25.8 \pm 4.3$ & 0.3 \\
\hline BMI Classes & & & & 0.006 \\
\hline Underweight & $12(1 \%)$ & $18(1.5 \%)$ & $24(2 \%)$ & \\
\hline Normal & $164(13.4 \%)$ & $156(12.8 \%)$ & $186(15.2 \%)$ & \\
\hline Overweight & $124(10.2 \%)$ & $136(11.1 \%)$ & $230(18.8 \%)$ & \\
\hline Obese & $64(5.2 \%)$ & $42(3.4 \%)$ & $66(5.4 \%)$ & \\
\hline Parity & & & & 0.1 \\
\hline Primiparous & $72(5.9 \%)$ & $90(7.4 \%)$ & $104(8.5 \%)$ & \\
\hline Multiparous & $292(23.9 \%)$ & $262(21.4 \%)$ & $402(32.9 \%)$ & \\
\hline Family Size & & & & 0.02 \\
\hline$\leq 4$ members & $240(19.7 \%)$ & $248(20.3 \%)$ & $298(24.4 \%)$ & \\
\hline$>4$ members & $124(10.1 \%)$ & $104(8.5 \%)$ & $208(12.8 \%)$ & \\
\hline Total income (SR) & & & & 0.08 \\
\hline$<3000$ & $78(6.4 \%)$ & $64(5.2 \%)$ & $123(10.1 \%)$ & \\
\hline $3001-5000$ & $196(16 \%)$ & $196(16 \%)$ & 250 (20.4\%) & \\
\hline $5001-10,000$ & $76(6.2 \%)$ & $68(5.6 \%)$ & 114 (9.3\%) & \\
\hline$>10,001$ & $14(1.2 \%)$ & $24(2 \%)$ & 19 (1.6\%) & \\
\hline Education Level & & & & $<0.001$ \\
\hline Illiterate & $16(1.3 \%)$ & $20(1.6 \%)$ & 40 (3.3\%) & \\
\hline $1^{\text {ry }}$ Education & $32(2.6 \%)$ & $26(2.1 \%)$ & $52(4.2 \%)$ & \\
\hline $2^{\text {ry }}$ Education & $76(6.2 \%)$ & 94 (7.7\%) & $172(14.1 \%)$ & \\
\hline University & 240 (19.7\%) & $212(17.4 \%)$ & 242 (19.8\%) & \\
\hline Employment & & & & 0.1 \\
\hline Yes & $92(7.5 \%)$ & 74 (6.1\%) & 100 (8.2\%) & \\
\hline No & $272(22.3 \%)$ & 278 (22.7\%) & 406 (33.2\%) & \\
\hline Residency & & & & 0.8 \\
\hline Urban & 356 (29.1\%) & 342 (28\%) & 494 (40.4\%) & \\
\hline Rural & $8(0.7 \%)$ & $10(0.8 \%)$ & $12(1 \%)$ & \\
\hline Active smoking & & & & 0.004 \\
\hline Yes & $8(0.7 \%)$ & 19 (1.6\%) & $37(3 \%)$ & \\
\hline No & 356 (29.1\%) & $333(27.2 \%)$ & 469 (38.4\%) & \\
\hline Passive smoking & & & & 0.2 \\
\hline Yes & $128(10.5 \%)$ & 112 (9.1\%) & 190 (15.5\%) & \\
\hline No & $236(19.3 \%)$ & $240(19.7 \%)$ & 316 (25.9\%) & \\
\hline
\end{tabular}


Table 1 The socioeconomic characteristics of the pregnant participants $(n=1222)$ (Continued)

\begin{tabular}{|c|c|c|c|c|}
\hline \multirow[t]{2}{*}{ Parameter } & \multicolumn{3}{|l|}{$\begin{array}{l}\text { Pregnant group } \\
(n=1222)\end{array}$} & \multirow[b]{2}{*}{ P-value } \\
\hline & $\begin{array}{l}\text { First trimester } \\
(n=364 ; 29.8 \%)\end{array}$ & $\begin{array}{l}\text { Second trimester } \\
(n=352 ; 28.8 \%)\end{array}$ & $\begin{array}{l}\text { Third trimester } \\
(n=506 ; 41.4 \%)\end{array}$ & \\
\hline Salt Intake & & & & 0.03 \\
\hline Don't know & $28(2.3 \%)$ & $12(1 \%)$ & $42(3.4 \%)$ & \\
\hline Non-iodised & $84(6.9 \%)$ & $82(6.7 \%)$ & $100(8.2 \%)$ & \\
\hline lodised & $252(20.6 \%)$ & $258(21.1 \%)$ & 364 (29.8\%) & \\
\hline lodine supplement & & & & 0.01 \\
\hline Yes & $80(6.6 \%)$ & 106 (8.7\%) & $152(12.4 \%)$ & \\
\hline No & $284(23.2 \%)$ & 246 (20.1\%) & 354 (29\%) & \\
\hline
\end{tabular}

above requirements during pregnancy, whereas the use of non-iodised salt (6-folds) and 2nd trimester (2.4-fold) were significantly associated with a decreased risk of iodine intake above requirements. Significant independent associations were also detected between the BMI and median UIC in the pregnant population.

\section{Discussion}

To the best of our knowledge, this study is the first to measure iodine adequacy in reproductive age and pregnant Saudi women. The majority of non-pregnant women $(73 \%)$ were using iodised salt, $2.8 \%$ were taking iodine supplements, and the median UIC was at the lowest WHO limit for iodine adequacy in reproductive age women [13]. In contrast, the pregnant group median UIC was below the WHO minimum for iodine sufficiency despite that iodised salt and/or daily iodine supplements were used by 71.5 and $27.6 \%$ of women, respectively. Our findings infer that the reproductive age Saudi women were marginally iodine sufficient, while the pregnant population had mild deficiency that could denote a public health burden [25-28].

The IGN report (2019) has classified the Saudi public as iodine sufficient based on a national SAC survey $[5,16]$. Others also showed iodine intake enhancement in SAC from a previously classified severe iodine deficient region after the execution of USI in KSA [33]. Contrariwise, severe iodine deficiency (median UIC $17 \mu \mathrm{g} / \mathrm{L}$ ) was reported in 3046 SAC from the same region, and $24 \%$ had goitre [25]. Iodine deficiency has also been reported in 1887 SAC (median UIC $84 \mu \mathrm{g} / \mathrm{L}$ ) from Makkah province, and $7.4 \%$ of them were goitrous [26]. Meanwhile $69 \%$ of local salt samples were adequately iodised (15-40 ppm), only $70 \%$ of the Saudi households were using iodised salt, which is below the USI target of $\geq 90 \%$ coverage [27]. Our non-pregnant results agree with the studies proclaiming iodine adequacy in the general Saudi public $[5,16,33]$. However, they were at the lowest margin of adequacy, which provides additional sustenance for the demands for banning non-iodised salt in KSA to enhance iodine intake [27].
On the other hand, our pregnant population had mild iodine deficiency at the different trimesters, and it was more pronounced with the non-use of iodine supplements. The daily iodine requirements increase immensely during pregnancy to compensate the physiological increase in iodine metabolism [28]. Hence, iodine deficiency in our pregnant population could be related to inappropriate nutrition since many studies have indicated malnourishment in Saudi pregnant women, and they consumed essential nutrients below the recommended requirements [34-37]. Saudi women from the Western region also had significantly low micronutrients intake, thus their offspring had a higher risk of developing birth defects [38-40]. In agreement, the use of iodine supplements was only confirmed by a minority $(27.6 \%)$ of our pregnant population. Accordingly, this study reinforces the many calls for improving awareness regarding the importance of iodine intake from dietary and supplement sources during pregnancy [41-44]. Moreover, insufficient iodine during pregnancy may precipitate maternal thyroid disorders alongside poor foetal neurodevelopment [1-4]. We have previously reported that 26.8 and $4.8 \%$ of 500 pregnant Saudi women had hypothyroidism and isolated hypothyroxinaemia, respectively [28]. However, little is known about the links between iodine intake and thyroid diseases among pregnant Saudi women. Hence, more studies to measure the associations between iodine intake and thyroid functions in pregnant Saudi women are needed.

Additionally, this study supports the notion that SAC median UIC could imprecisely reflect iodine status in pregnancy [7-11]. In consolidation, The IGN has revealed that 29 countries reported iodine deficiency in pregnant women despite that their SAC were sufficient [45]. The UNICEF guidelines have likewise stated that median UIC may conceal suboptimal iodine intake in pregnant women [17]. Studies from different countries have also demonstrated marked iodine insufficiency among pregnant women despite using iodised salt and/ or iodine supplements $[7,9,11]$. Taken together, our 
Table 2 The socioeconomic risk factors associated with insufficient and excess iodine intake among the non-pregnant participants $(n=400)$ by multinomial regression analysis

\begin{tabular}{|c|c|c|c|c|}
\hline \multirow[t]{2}{*}{ Risk factors } & \multicolumn{2}{|c|}{ Insufficiency $(<100 \mu \mathrm{g} / \mathrm{L})$} & \multicolumn{2}{|l|}{$\begin{array}{l}\text { Above requirements } \\
(\geq 200 \mu \mathrm{g} / \mathrm{L})\end{array}$} \\
\hline & Odds ratio $(95 \% \mathrm{Cl})$ & $P$ Value & Odds ratio $(95 \% \mathrm{Cl})$ & $P$ Value \\
\hline Age (years) & $1.017(0.983-1.052)$ & NS & $0.978(0.919-1.041)$ & NS \\
\hline BMI $\left(\mathrm{Kg} / \mathrm{m}^{2}\right)$ & $1.004(0.959-1.051)$ & NS & 1.084 (1.010-1.163) & $P=0.02$ \\
\hline \multicolumn{5}{|l|}{ Parity } \\
\hline Primiparous & Ref. & & Ref. & \\
\hline Multiparous & $3.091(1.707-5.598)$ & $P<0.0001$ & $0.607(0.214-1.724)$ & NS \\
\hline \multicolumn{5}{|l|}{ Family Size } \\
\hline$\leq 4$ members & Ref. & & Ref. & \\
\hline$>4$ members & $2.390(1.390-4.112)$ & $P=0.02$ & $2.102(0.843-5.242)$ & NS \\
\hline \multicolumn{5}{|l|}{ Total income (SR) } \\
\hline$<3000$ & $2.520(1.038-6.119)$ & $P=0.04$ & $1.452(0.333-6.338)$ & NS \\
\hline $3001-5000$ & $1.465(0.740-2.902)$ & NS & $0.755(0.219-2.595)$ & NS \\
\hline $5001-10,000$ & $1.552(0.769-3.012)$ & NS & $0.707(0.203-2.458)$ & NS \\
\hline$>10,001$ & Ref. & & Ref. & \\
\hline \multicolumn{5}{|l|}{ Education Level } \\
\hline Illiterate & $1.387(0.355-5.416)$ & NS & $9.884(2.028-48.163)$ & $P<0.01$ \\
\hline Primary Education & $0.549(0.224-1.344)$ & NS & $4.212(1.218-14.570)$ & $P=0.02$ \\
\hline Secondary Education & $1.087(0.639-1.848)$ & NS & $1.774(0.662-4.596)$ & NS \\
\hline University & Ref. & & Ref. & \\
\hline \multicolumn{5}{|l|}{ Employment } \\
\hline Yes & $1.009(0.546-1.867)$ & NS & $0.769(0.273-2.165)$ & NS \\
\hline No & Ref. & & Ref. & \\
\hline \multicolumn{5}{|l|}{ Active smoking } \\
\hline Yes & $1.226(0.394-3.815)$ & NS & $0.699(0.069-7.043)$ & NS \\
\hline No & Ref. & & Ref. & \\
\hline \multicolumn{5}{|l|}{ Passive smoking } \\
\hline Yes & $1.818(1.097-3.014)$ & $P=0.02$ & $1.309(0.549-3.125)$ & NS \\
\hline No & Ref. & & Ref. & \\
\hline \multicolumn{5}{|l|}{ Salt Intake } \\
\hline lodized & Ref. & & Ref. & \\
\hline Non-iodized & $2.052(1.118-3.766)$ & $P=0.02$ & $1.247(0.420-3.700)$ & NS \\
\hline Don't know & $0.449(0.161-1.251)$ & NS & $0.753(0.167-3.398)$ & NS \\
\hline \multicolumn{5}{|l|}{ lodine supplement } \\
\hline Yes & $0.364(0.172-0.771)$ & $P<0.01$ & 1.367 (0.479-3.900) & NS \\
\hline No & Ref. & & & \\
\hline
\end{tabular}

Ref Reference category

NS Non-significant

study and the prior reports advocate that the health authorities in each country should consider measuring UIC independently from SAC to accurately evaluate iodine intake in pregnant women [7-11]. Educational programs should also be developed to increase the awareness of pregnant women, or those who are planning for conception, about the significance of iodine for them and for their offspring wellbeing $[46,47]$.

Measuring composite 24-h UIC is the reference biochemical approach for accurately assessing iodine status [13-15]. However, compliance with the collection of 24$\mathrm{h}$ urine is low and, therefore, spot UIC as well as 

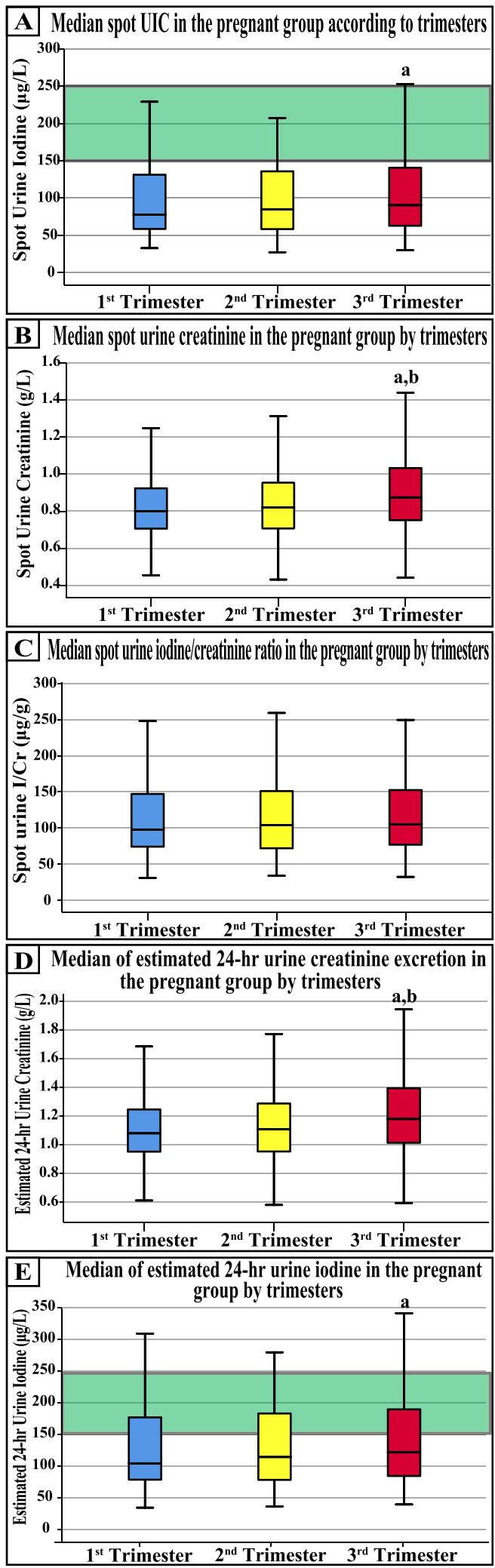

Fig. 1 The median of (a) spot urine iodine concentrations, (b) spot urine creatinine concentrations, (c) urine spot iodine/creatinine ratio, (d) estimated 24-h urine creatinine excretion and (e) estimated 24-h urine iodine excretion in each trimester of pregnancy. $(\mathrm{a}=P<0.05$ compared with the 1 st trimester and $\mathrm{b}=\mathrm{P}<0.05$ compared with 2nd trimester by one-way ANOVA and green rectangle $=$ the recommended $\mathrm{WHO}$ intervals for iodine adequacy in pregnant women)

estimating 24-h UIE have been suggested as convenient and accurate alternative methods for measuring iodine intake [13-15]. Our results demonstrated that the spot I/Cr ratio and the estimated 24-h UIE results were comparable in each of the targeted populations, which agree with numerous earlier studies that recommended the use of spot UIC as an alternative reliable method for estimating iodine status $[14,15,48]$.

Iodine adequacy could be influenced by numerous factors [49]. Herein, the risk of iodine deficiency in the non-pregnant population increased with multiparity, which agrees with studies from numerous Western countries [50-53]. A possible construal for the associations between parity and iodine intake could be illustrated by the proclaimed cumulative and non-reversible goitrogenic effects associated with each pregnancy, which may require increasing iodine supply in subsequent pregnancies [54]. Additionally, earning below the Saudi minimal wage also increased the odds of inadequate iodine in our non-pregnant women. Likewise, a linkage between poverty and iodine inadequacy has been reported by community studies, which could be due poor adherence of low-income populations to appropriate micronutrients and iodised salt intake $[55,56] . \mathrm{Nu}-$ merous population-based studies have also demonstrated the negative impact of smoking on thyroid functions and iodine adequacy in reproductive age and pregnant women [49, 51, 52, 57, 58]. In agreement, our data showed that passive smoking was an independent factor that significantly increased the risk of iodine inadequacy in both the non-pregnant and pregnant groups. Accordingly, this study strengthens the numerous requests to employ the necessary policies for smoking cessation as well as to encourage pregnant women to avoid staying in rooms where others have smoked [59].

Our results also revealed higher risks of iodine insufficiency associated with the consumption of non-iodised salt in the reproductive age and pregnant women. The WHO and UNICEF have adopted the USI policy since 1994 to ensure adequate iodine intake by the general public [60]. Although USI is implemented in KSA, the household consumption of iodised salt (70\%) was below the targeted $90 \%$ usage by the general population to avoid deficiency [27]. Recently, the WHO has also recommended salt reduction ( $5 \mathrm{~g} /$ day) for adults, including 
Table 3 The socioeconomic risk factors associated with insufficient and excess iodine intake among the pregnant participants $(n=1222)$ by multinomial regression analysis

\begin{tabular}{|c|c|c|c|c|}
\hline \multirow[t]{2}{*}{ Risk factors } & \multicolumn{2}{|c|}{ Insufficiency $(<150 \mu \mathrm{g} / \mathrm{L})$} & \multicolumn{2}{|c|}{ Above requirements ( $\geq 250 \mu \mathrm{g} / \mathrm{L}$ ) } \\
\hline & Odds ratio $(95 \% \mathrm{Cl})$ & $P$ Value & Odds ratio $(95 \% \mathrm{Cl})$ & P Value \\
\hline Age (years) & $1.007(0.968-1.048)$ & NS & $0.979(0.924-1.036)$ & NS \\
\hline BMI $\left(\mathrm{Kg} / \mathrm{m}^{2}\right)$ & $0.951(0.913-0.991)$ & $P=0.01$ & $1.090(1.013-1.173)$ & $P=0.02$ \\
\hline \multicolumn{5}{|l|}{ Pregnancy groups } \\
\hline 1st Trimester & $1.384(0.858-2.231)$ & NS & $0.957(0.481-1.902)$ & NS \\
\hline 2nd Trimester & $1.092(0.682-1.747)$ & NS & $0.407(0.175-0.947)$ & $P=0.03$ \\
\hline 3rd Trimester & Ref. & & Ref. & \\
\hline \multicolumn{5}{|l|}{ Parity } \\
\hline Primiparous & Ref. & & Ref. & \\
\hline Multiparous & $0.862(0.507-1.464)$ & NS & $1.637(0.606-4.421)$ & NS \\
\hline \multicolumn{5}{|l|}{ Family Size } \\
\hline$\leq 4$ members & Ref. & & Ref. & \\
\hline$>4$ members & $0.691(0.427-1.118)$ & NS & $0.823(0.406-1.668)$ & NS \\
\hline \multicolumn{5}{|l|}{ Education Level } \\
\hline Illiterate & $0.953(0.372-2.440)$ & NS & $1.607(0.596-4.335)$ & NS \\
\hline Primary Education & $1.487(0.709-3.117)$ & NS & $1.096(0.322-3.735)$ & NS \\
\hline Secondary Education & $0.778(0.490-1.234)$ & NS & $1.305(0.605-2.813)$ & NS \\
\hline University & Ref. & & Ref. & \\
\hline \multicolumn{5}{|l|}{ Employment } \\
\hline Yes & $1.182(0.716-1.950)$ & NS & $1.082(0.440-2.659)$ & NS \\
\hline No & Ref. & & Ref. & \\
\hline \multicolumn{5}{|l|}{ Active smoking } \\
\hline Yes & $1.996(0.648-6.144)$ & NS & $0.445(0.056-3.525)$ & NS \\
\hline No & Ref. & & Ref. & \\
\hline \multicolumn{5}{|l|}{ Passive smoking } \\
\hline Yes & $1.653(1.043-2.618)$ & $P=0.03$ & $1.039(0.528-2.043)$ & NS \\
\hline No & Ref. & & Ref. & \\
\hline \multicolumn{5}{|l|}{ Salt Intake } \\
\hline lodized & Ref. & & Ref. & \\
\hline Non-iodized & $3.813(1.992-7.297)$ & $P<0.001$ & $0.157(0.036-0.685)$ & $P=0.01$ \\
\hline Don't know & $3.444(1.287-9.214)$ & $P=0.01$ & $1.505(0.551-4.117)$ & NS \\
\hline \multicolumn{5}{|l|}{ lodine supplement } \\
\hline Yes & $0.002(0.001-0.005)$ & $P<0.0001$ & $0.936(0.478-1.835)$ & NS \\
\hline No & Ref. & & & \\
\hline
\end{tabular}

Ref Reference category

NS Non-significant

reproductive age and pregnant women, to reduce the likelihood of developing cardiovascular diseases [6]. Suggested plans to simultaneously maintain iodine adequacy with decreasing salt intake include fortifying salt with higher amounts of iodine [6]. Alternatively, Australia and New Zealand have adopted another strategy involving fortifying bread with iodine, and several studies have reported adequate median UIC in adults, including pregnant women, post-fortification $[61,62]$. Therefore, the inadequate use of iodised salt in KSA alongside the recommended reduction of salt intake accentuate the importance of developing other vehicle(s) for delivering iodine, thus decreasing iodine deficiency disorders [61, 62]. Additionally, the non-pregnant and pregnant women who reported using iodine supplements in our study were iodine sufficient, whereas those who were not using iodine supplements had iodine insufficiency. Hence, reproductive age $(150 \mu \mathrm{g} /$ day $)$ and pregnant $(250 \mu \mathrm{g} /$ day $)$ women could 
temporarily benefit from using daily iodine supplements till developing a solid and effective national salt/bread iodisation program [27, 61, 62].

Herein, a weak positive association between BMI and UIC was observed, which correlates with previous reports from Bangladesh and Romania [63, 64]. A possible explanation could be that pregnant and non-pregnant women with high BMI were consuming higher foods rich in iodine than lean individuals. Additionally, pregnant women often change their dietary habits and obese women tend to eat more fish and milk, the richest sources of iodine [65]. On the contrary, others have reported either negative association between BMI and UIC $[9,66]$ or no correlation between body weight and iodine intake $[8,41]$. These controversial results could be linked to different eating habits and/or dietary patterns between the studied populations $[67,68]$.

The present study has several limitations. Although the number of participants is larger compared with several other reports on pregnant women [7-9], our participants were enrolled from a single site, and other cities from the same region were not included. Additionally, we did not measure the dietary habits and nutritional intake alongside the thyroid function parameters to investigate their correlations with iodine status. However, this is a phase 1 study and we will conduct further research to measure the interactions between nutritional habits, iodine intake and thyroid functions in pregnant women.

\section{Conclusions}

This is the first study to demonstrated borderline iodine sufficiency among reproductive age women from the Western region of Saudi Arabia, whereas the pregnant women were deficient, despite the use of iodised salt. Similar to other countries, this study highlighted the need to survey iodine intake in pregnant women regularly and independently from schoolchildren. Although the use of iodine supplements was associated with a significant decreased risk of deficiency among the targeted populations, less than $30 \%$ of pregnant women reported using supplements rich in iodine. Hence, our findings advocate the necessity to develop/implement effective national programs in the different regions of KSA to overcome any potential complications arising from suboptimal iodine intake during pregnancy. Suggested actions include developing educational and awareness campaigns regarding the importance of iodine, and to encourage adequate nutritional schemes based on diets rich in iodine (e.g. fish, milk, iodised salt intake and iodine fortified foods). However, further studies are mandatory to assess the factual magnitude as well as the potential complications of iodine deficiency during pregnancy in the kingdom.

\section{Supplementary information}

Supplementary information accompanies this paper at https://doi.org/10. 1186/s12884-020-03057-w.

Additional file 1.

Additional file 2: Table S1. The demographic and socioeconomic characteristics of the non-pregnant participants $(n=400)$.

\section{Abbreviations}

24-h Cr: 24-h urine creatinine excretion; 24-h UIE: Estimated 24-h urine iodine excretion; BMI: Body mass index; KSA: Kingdom of Saudi Arabia; I/Cr: Iodine/ creatinine ratio; IGN: Iodine Global Network; IQR: Interquartile range; $\mathrm{KIO}_{3}$ : Potassium iodate; SAC: School-age children; SAR: Saudi Riyal; SD: Standard deviation; UIC: Urine iodine concentration; USI: Universal salt iodisation; WHO: World Health Organisation

\section{Acknowledgments}

The authors acknowledge the dietitians (Amjad Alosaimi, Ebtehal Maghrabi, Ethar Almabadi, Ethar Almabouth, Lina Alqahtani, Munirah Amen, Raghad Alharbi, and Sara Alyasi) from the Clinical Nutrition Department, Faculty of Applied Medical Sciences, Umm Al-Qura University for assisting in collecting the survey data.

The authors would also like to thank Mr. Jawwad Ahmad and Mr. Shakir Idris from the Laboratory Medicine Department, Faculty of Applied Medical Sciences, Umm Al-Qura University for processing the samples.

The authors also acknowledge Dr. A Aslam, Assistant Professor of Immunology from the Laboratory Medicine Department, Faculty of Applied Medical Sciences, Umm Al-Qura University for proof editing the manuscript.

\section{Authors' contributions}

Conceptualization: FA \& BR; methodology: FA \& BR; formal analysis: FA \& BR; investigation: FA \& BR; funding acquisition: $B R \& F A$; resources and project administration: BR; data curation: FA; writing —original and revised draft: FA \& BR; supervision: FA. Both authors have read and approved the manuscript.

\section{Funding}

This project was funded by the DEANSHIP OF SCIENTIFIC RESEARCH AT UMM AL-QURA UNIVERSITY; Project (15-MED-3-1-0054). The funding organisation had no role in the study design, data collection, analysis, interpretation, or manuscript writing.

\section{Availability of data and materials}

All data generated or analysed during this study are included in this published article and its supplementary information files (Supplementary files 1 and 2).

\section{Ethics approval and consent to participate}

Ethical approval was obtained the Faculty of Applied Medical Sciences Ethics Committee (AMSEC 21-16-02-2017). Informed written consent was also obtained from all participants included in the study.

\section{Consent for publication}

Not applicable.

\section{Competing interests}

The authors declare no conflict of interest.

\section{Author details}

${ }^{1}$ Clinical Nutrition Department, Faculty of Applied Medical Sciences, Umm Al-Qura University, Al Abdeyah, PO Box 7607, Makkah, Saudi Arabia.

${ }^{2}$ Laboratory Medicine Department, Faculty of Applied Medical Sciences, Umm Al-Qura University, Al Abdeyah, Holy Makkah, PO Box 7607, Makkah, Saudi Arabia. 
Received: 2 September 2019 Accepted: 16 June 2020

Published online: 22 June 2020

\section{References}

1. Rostami R, Beiranvand A, Khakhali H, Salary S, Aghasi M, Nourooz-Zadeh J. Evaluation of accessibility of iodinated salt and nutritional iodine status during pregnancy. Iran J Public Health. 2012;41:56-60.

2. Mao J, Pop VJ, Bath SC, Vader HL, Redman CW, Rayman MP. Effect of lowdose selenium on thyroid autoimmunity and thyroid function in UK pregnant women with mild-to-moderate iodine deficiency. Eur J Nutr. 2014. https://doi.org/10.1007/s00394-014-0822-9.

3. Bath SC, Steer CD, Golding J, Emmett P, Rayman MP. Effect of inadequate iodine status in UK pregnant women on cognitive outcomes in their children: results from the Avon longitudinal study of parents and children (ALSPAC). Lancet. 2013;382:331-7.

4. Pearce EN, Lazarus JH, Moreno-Reyes R, Zimmermann MB. Consequences of iodine deficiency and excess in pregnant women: an overview of current knowns and unknowns. Am J Clin Nutr. 2016;104:918S-23S.

5. The lodine Global Network. Global scorecard of iodine nutrition in 2019 in the general population based on school-age children (SAC). 2019; Available from: http://www.ign.org/cm_data/Global_Scorecard_2019_SAC.pdf [Accessed 24 Aug 2019].

6. World Health Organization. Salt reduction and iodine fortification strategies in public health: report of a joint technical meeting convened by the World Health Organization and The George Institute for Global Health in collaboration with the International Council for the Control of lodine Deficiency Disorders Global Network, Sydney, Australia, March 2013. 2014, Geneva: World Health Organization. Available from: http://apps.who.int/iris/ handle/10665/101509 [Accessed 24 Aug 2019].

7. Lindorfer H, Krebs M, Kautzky-Willer A, Bancher-Todesca D, Sager M, Gessl A. lodine deficiency in pregnant women in Austria. Eur J Clin Nutr. 2015;69: 349-54

8. Granfors M, Andersson M, Stinca S, Akerud H, Skalkidou A, Poromaa IS, Wikstrom AK, Nystrom HF. lodine deficiency in a study population of pregnant women in Sweden. Acta Obstet Gynecol Scand. 2015;94:1168-74.

9. Kirkegaard-Klitbo DM, Perslev K, Andersen SL, Perrild H, Knudsen N, Weber T, Rasmussen LB, Laurberg P. lodine deficiency in pregnancy is prevalent in vulnerable groups in Denmark. Dan Med J. 2016;63:1-5.

10. Ovadia YS, Arbelle JE, Gefel D, Brik H, Wolf T, Nadler V, Hunziker S, Zimmermann MB, Troen AM. First Israeli National lodine Survey Demonstrates lodine Deficiency among School-Aged Children and pregnant women. Thyroid. 2017;27:1083-91.

11. Wang Z, Zhu W, Mo Z, Wang Y, Mao G, Wang X, Lou X. An increase in consuming adequately iodized salt may not be enough to rectify iodine deficiency in pregnancy in an iodine-sufficient area of China. Int J Environ Res Public Health. 2017:14:206. https://doi.org/10.3390/ijerph14020206.

12. World Health Organization. lodine supplementation in pregnant and lactating women. 2007; Available from: https://www.who.int/elena/titles/ guidance_summaries/iodine_pregnancy/en/ [Accessed 31 Dec 2019].

13. World Health Organization. Urinary iodine concentrations for determining iodine status in populations. 2013; Available from: http://www.who.int/iris/ handle/10665/85972 [Accessed 24 Aug 2019].

14. Perrine CG, Cogswell ME, Swanson CA, Sullivan KM, Chen TC, Carriquiry AL, Dodd KW, Caldwell KL, Wang CY. Comparison of population iodine estimates from 24-hour urine and timed-spot urine samples. Thyroid. 2014 24:748-57.

15. Haap M, Roth HJ, Huber T, Dittmann H, Wahl R. Urinary iodine: comparison of a simple method for its determination in microplates with measurement by inductively-coupled plasma mass spectrometry. Sci Rep. 2017;7:39835.

16. Al-Dakheel MH, Haridi HK, Al-Bashir BM, Al-Shingiti A, Al-Shehri S, Gassem MA, Hussein I. Prevalence of iodine deficiency disorders among school children in Saudi Arabia: results of a national iodine nutrition study. East Mediterr Health J. 2016:22:301-8.

17. UNICEF. Guidance on the Monitoring of Salt lodization Programmes and Determination of Population lodine Status. 2018; Available from: https:// www.unicef.org/nutrition/files/Monitoring-of-Salt-lodization.pdf [Accessed 202003 Jan 2020]

18. Al-Jurayyan NA, Al-Nuaim AA, Redha MA, El-Desouki Ml, Al Herbish AS, Abo Bakr AM, Al Swailem AA, Al Mazrou YY, AI DA. Neonatal screening for congenital hypothyroidism in Riyadh: analysis of six year's experience. Ann Saudi Med. 1996;16:20-3.
19. Al-Jurayyan NA, Al-Herbish AS, El-Desouki Ml, Al-Nuaim AA, Abo-Bakr AM, AlHusain MA. Congenital anomalies in infants with congenital hypothyroidism: is it a coincidental or an associated finding? Hum Hered. 1997;47:33-7.

20. Al-Maghamsi MS, Al-Hawsawi ZM, Ghulam GN, Okasha AM. Screening for congenital hypothyroidism in north-west region of Saudi Arabia. Saudi Med J. 2002;23:1518-21.

21. Al-Alwan I, AlRowaeah A, Bawazeer M. Diagnosed congenital hypothyroidism with missing follow-up: is it time for a national registry? Ann Saudi Med. 2012:32:652-5.

22. Abdullah M.A., Salhi H. and al Herbish A.A. Childhood goitre in Saudi Arabia. Ann Trop Paediatr. 1997,17:233-8.

23. Abu-Eshy SA, Abolfotouh MA, Al-Naggar YM. Endemic goitre in schoolchildren in high and low altitude areas of Asir region, Saudi Arabia. Saudi Med J. 2001;22:146-9.

24. Alissa EM, AIShali K, Ferns GA. lodine deficiency among hypothyroid patients living in Jeddah. Biol Trace Elem Res. 2009;130:193-203.

25. Abbag Fl, Abu-Eshy SA, Mahfouz AA, Al-Fifi SA, El-Wadie H, Abdallah SM Musa MG, Devansan CS, Patel A. lodine-deficiency disorders in the Aseer region, South-Western Saudi Arabia: 20 years after the national survey and universal salt iodization. Public Health Nutr. 2015;18:2523-9.

26. Omar MS, El-Sayed DD. Environmental, urinary iodine status and prevalence of goitre among schoolchildren in a high altitude area of Saudi Arabia. Pak J Med Sci. 2015:31:414-9.

27. Al-Dakheel MH, Haridi HK, Al-Bashir BM, Al-Shangiti AM, Al-Shehri SN, Hussein I. Assessment of household use of iodized salt and adequacy of salt iodization: a cross-sectional National Study in Saudi Arabia. Nutr J. 2018;17:35.

28. Refaat B. Prevalence of pregnancy induced thyroid dysfunction and the characteristics of the associated anaemia in primigravida Saudi women during the first trimester: a cross sectional study. Gazz Med Ital-AechSci Med. 2014:173:1-2.

29. General Authority for Statistics. Statistical Yearbook of 2017 | Issue Number: 53. 2017; Available from: https:/www.stats.gov.sa/en/929-0 [Accessed 12 Jan 2018]

30. Saudi Minsitry of Health. Annual Statistical Book. 2018: Saudi Arabia p 231. Available from: https://www.moh.gov.sa/en/Ministry/Statistics/book Documents/ANNUAL-STATISTICAL-BOOK-1438H.pdf [Accessed 12 Jan 2018].

31. Jones E, McLean R, Davies B, Hawkins R, Meiklejohn E, Ma ZF, Skeaff S. Adequate iodine status in New Zealand school children post-fortification of bread with iodised salt. Nutrients. 2016:8:298. https://doi.org/10.3390/ nu8050298.

32. Mage DT, Allen RH, Kodali A. Creatinine corrections for estimating children's and adult's pesticide intake doses in equilibrium with urinary pesticide and creatinine concentrations. J Expo Sci Environ Epidemiol. 2008;18:360-8.

33. Alsanosy RM, Gaffar AM, Khalafalla HE, Mahfouz MS, Zaid AN, Bani IA. Current iodine nutrition status and progress toward elimination of iodine deficiency disorders in Jazan, Saudi Arabia. BMC Public Health. 2012;12:1006.

34. Mansour AA, Hassan SA. Factors that influence women's nutrition knowledge in Saudi Arabia. Health Care Women Int. 1994;15:213-23.

35. Almurshed KS, Bani IA, Al-Kanhal MA, Al-Amri MA. A study of maternal dietary intake during pregnancy in Riyadh, Saudi Arabia. J Family Community Med. 2007;14:9-13.

36. Moradi-Lakeh M, El Bcheraoui C, Afshin A, Daoud F, AlMazroa MA, Al SM, Basulaiman M, Memish ZA, Al Rabeeah AA, Mokdad AH. Diet in Saudi Arabia: findings from a nationally representative survey. Public Health Nutr. 2017;20:1075-81.

37. Al BT, Doweri AA, Sawadi RM, Awaji MY, Jarad MM, Sulays ZY, Madkor KA. Consumption habits of pregnant women in the Jazan region, Saudi Arabia: a descriptive study. BMC Res Notes. 2018;11:817.

38. Ibrahim SA, Al-Halim OAFA, Samy MA, Mohamadin AM. Maternal nutritional status and the risk of birth defects among Saudi women. Nutrafoods. 2013;12:81-8.

39. Hammouda SA, Abd Al-Halim OA, Mohamadin AM. Serum levels of some micronutrients and congenital malformations: a prospective cohort study in healthy saudi-arabian first-trimester pregnant women. Int I Vitam Nutr Res. 2013;83:346-54

40. AIShail E, De Vol E, Yassen A, Elgamal EA. Epidemiology of neural tube defects in Saudi Arabia. Saudi Med J. 2014;35(Suppl 1):S68-71.

41. McMullan P, Hamill L, Doolan K, Hunter A, McCance D, Patterson C, Smyth P, Woodside JV, Mullan K. lodine deficiency among pregnant women living in Northern Ireland. Clin Endocrinol. 2019. https://doi.org/10.1111/cen.14065.

42. Mitchell EKL, Martin JC, D'Amore A, Francis I, Savige GS. Maternal iodine dietary supplements and neonatal thyroid stimulating hormone in Gippsland, Australia. Asia Pac J Clin Nutr. 2018;27:848-52. 
43. Dahl L, Wik MM, Sanchez PVR, Moe V, Smith L, Meltzer HM, Kjellevold M. lodine deficiency in a study population of Norwegian pregnant womenresults from the little in Norway study (LiN). Nutrients. 2018;10:513. https:// doi.org/10.3390/nu10040513.

44. Monahan M, Boelaert K, Jolly K, Chan S, Barton P, Roberts TE. Costs and benefits of iodine supplementation for pregnant women in a mildly to moderately iodine-deficient population: a modelling analysis. Lancet Diabetes Endocrinol. 2015;3:715-22.

45. Gizak M., Rogers L., Gorstein J., Zimmermann M. and Andersson M. Global lodine Status in School-Age Children, Women of Reproductive Age, and Pregnant Women in 2017. in American Society for Nutrition (ASN) Nutrition Conference 2018. 2018. Boston, USA.

46. Panth $P$, Guerin G, DiMarco NM. A review of iodine status of women of reproductive age in the USA. Biol Trace Elem Res. 2019;188:208-20.

47. Amiri P, Hamzavi ZN, Nazeri P, Ghofranipour F, Karimi M, Amouzegar A, Mirmiran P, Azizi F. Can an educational intervention improve iodine nutrition status in pregnant women? A Randomized Controlled Trial. Thyroid. 2017;27:418-25.

48. Vejbjerg P, Knudsen N, Perrild H, Laurberg P, Andersen S, Rasmussen LB, Ovesen $L$, Jørgensen $T$. Estimation of iodine intake from various urinary iodine measurements in population studies. Thyroid. 2009;19:1281-6.

49. Henjum S, Brantsaeter AL, Kurniasari A, Dahl L, Aadland EK, Gjengedal ELF, Birkeland S, Aakre I. Suboptimal iodine status and low iodine knowledge in young Norwegian women. Nutrients. 2018;10:941. https://doi.org/10.3390/ nu10070941.

50. Yehuda M, Wang CH, Pak Y, Chiu KC, Gianoukakis AG. Parity and Risk of Thyroid Autoimmunity Based on the NHANES (2001-2002, 2007-2008, 20092010, and 2011-2012). J Clin Endocrinol Metab. 2017(102):3437-42.

51. Andersen SL, Olsen J, Laurberg P. Maternal thyroid disease in the Danish National Birth Cohort: prevalence and risk factors. Eur J Endocrinol. 2016; 174:203-12.

52. Farahati J, Wegscheider K, Christ K, Gilman E, Oing W. Gender-specific determinants of goiter. Biol Trace Elem Res. 2006;113:223-30.

53. Rotondi M, Sorvillo F, Mazziotti G, Balzano S, lorio S, Savoia A, Piscopo M, Biondi B, Amato G, Carella C. The influence of parity on multinodular goiter prevalence in areas with moderate iodine deficiency. J Endocrinol Investig. 2002;25:442-6.

54. Rotondi M, Amato G, Biondi B, Mazziotti G, Del Buono A, Rotonda NM, Balzano S, Bellastella A, Glinoer D, Carella C. Parity as a thyroid sizedetermining factor in areas with moderate iodine deficiency. J Clin Endocrinol Metab. 2000;85:4534-7.

55. Pandav CS, Yadav K, Salve HR, Kumar R, Goel AD, Chakrabarty A. High national and sub-national coverage of iodised salt in India: evidence from the first National lodine and salt intake survey (NISI) 2014-2015. Public Health Nutr. 2018;21:3027-36.

56. Magri F, Zerbini F, Gaiti M, Capelli V, Croce L, Bini S, Rigamonti AE, Fiorini G, Cella SG, Chiovato L. Poverty and immigration as a barrier to iodine intake and maternal adherence to iodine supplementation. J Endocrinol Investig. 2019;42:435-42.

57. Volzke H, Schwahn C, Kohlmann T, Kramer A, Robinson DM, John U, Meng W. Risk factors for goiter in a previously iodine-deficient region. Exp Clin Endocrinol Diabetes. 2005;113:507-15.

58. Karmakar N, Datta A, Nag K, Datta SS, Datta S. Knowledge, attitude, and practice regarding household consumption of iodized salt among rural women of Tripura, India: A mixed-methods study. J Educ Health Promot. 2019;8:21.

59. Koletzko B, Bauer CP, Bung P, Cremer M, Flothkotter M, Hellmers C, Kersting M, Krawinkel M, Przyrembel H, Rasenack R, Schafer T, Vetter K, Wahn U, Weissenborn A, Wockel A. German national consensus recommendations on nutrition and lifestyle in pregnancy by the 'Healthy start - young family Network'. Ann Nutr Metab. 2013;63:311-22.

60. Andersson M, de Benoist B, Delange F, Zupan J. Prevention and control of iodine deficiency in pregnant and lactating women and in children less than 2-years-old: conclusions and recommendations of the technical consultation. Public Health Nutr. 2007;10:1606-11.

61. Brough L, Jin Y, Shukri NH, Wharemate ZR, Weber JL, Coad J. lodine intake and status during pregnancy and lactation before and after government initiatives to improve iodine status, in Palmerston North, New Zealand: a pilot study. Matern Child Nutr. 2015;11:646-55.

62. Condo D, Huyhn D, Anderson AJ, Skeaff S, Ryan P, Makrides M, Muhlhausler BS, Zhou SJ. lodine status of pregnant women in South Australia after mandatory iodine fortification of bread and the recommendation for iodine supplementation. Matern Child Nutr. 2017;13:e12410. https://doi.org/10. 1111/men.12410.

63. Rydbeck F, Bottai M, Tofail F, Persson LA, Kippler M. Urinary iodine concentrations of pregnant women in rural Bangladesh: a longitudinal study. J Expo Sci Environ Epidemiol. 2014;24:504-9.

64. Ursu HI, Toader OD, Podia-Igna C, Delia CE, Firta AR, Tupea CC, Tudor LM, Gheorghiu ML, Suciu N. lodine status in pregnant women after a decade of universal salt iodization in Romania. Acta Endocrinol (Buchar). 2016;12:161-7.

65. Forbes LE, Graham JE, Berglund C, Bell RC. Dietary change during pregnancy and Women's reasons for change. Nutrients. 2018;10:1032. https://doi.org/10.3390/nu10081032.

66. Jaiswal N, Melse-Boonstra A, Thomas T, Basavaraj C, Sharma SK, Srinivasan K, Zimmermann MB. High prevalence of maternal hypothyroidism despite adequate iodine status in Indian pregnant women in the first trimester. Thyroid. 2014;24:1419-29.

67. Bzikowska A, Czerwonogrodzka-Senczyna A, Riahi A, Weker H. Nutritional value of daily food rations of overweight and normal weight pregnant women. Rocz Panstw Zakl Hig. 2017;68:375-9.

68. Shin D, Lee KW, Song WO. Pre-pregnancy weight status is associated with diet quality and nutritional biomarkers during pregnancy. Nutrients. 2016;8:162.

\section{Publisher's Note}

Springer Nature remains neutral with regard to jurisdictional claims in published maps and institutional affiliations.
Ready to submit your research? Choose BMC and benefit from:

- fast, convenient online submission

- thorough peer review by experienced researchers in your field

- rapid publication on acceptance

- support for research data, including large and complex data types

- gold Open Access which fosters wider collaboration and increased citations

- maximum visibility for your research: over $100 \mathrm{M}$ website views per year

At BMC, research is always in progress.

Learn more biomedcentral.com/submissions 